\title{
Psychotherapy as Practice of Myself
}

\author{
Ludmila Vorobyova \\ The Federal State Scientific Institution "Psychological Institute" of the Russian Academy of Education, Russia
}

Copyright (C) 2016 by authors, all rights reserved. Authors agree that this article remains permanently open access under the terms of the Creative Commons Attribution License 4.0 International License

\begin{abstract}
The article is devoted to philosophical consideration of psychotherapeutic discourse in social and cultural context. The author uses the archaeological method of Michel Foucault, focusing on the analysis of the changes in the medical discourse of psychiatry that occurred with the advent of psychoanalysis on the «axis» of power and ethos.
\end{abstract}

Keywords Psychotherapy, Foucault, Power, Ethos, Psychoanalysis

\section{Headnote}

Philosophical investigations psychotherapy historically presented two traditions. The first consisted of works which set the purpose to answer the question of scientific status of psychotherapy or about belonging it to one or another type of sciences (K. Popper, A. Grünbaum, N.S. Avtonomova, etc.). The second aimed at trying to find arguments in favor of understanding fenomenological-germeneutics method as a method of generating meaning in the psychotherapeutic process (A. Lorenzer, J. Habermas, M.K. Mamardashvily, L. Sass, M. McDonald \& S. Wearing, etc.). Sharing the fenomenological-germeneutics interpretation of the psychotherapeutic method, I believe that philosophical analysis of psychotherapy should be extended by the inclusion of the archaeological method of Michel Foucault. This means understanding psychotherapy as a discursive practice in the unity of the three dimensions: knowledge power - ethos, systemically interconnected [1]. This will consider psychotherapy in the social and cultural context, while at the same time, philosophical research of it overcome the narrow confines of the epistemological problems. This paper will focus on the analysis of psychotherapeutic discourse on the «axises» of power and ethos.

\section{Two Types of Anthropological Practices}

According to M. Foucault, there are two types of anthropological practices in Western history: the practice of power and those, he calls «practice of myself». Changing the practices of the first type in the transition to modernity consisted in the withering away of direct repressive power technology and the emergence of a new kind of power - the «power-normalization»: Norm - writes Foucault, contains within itself the principles of transformation and renewal, it «is the bearer of a certain power claims. $<\ldots>\ldots$ norm implies at the same time both the principle of qualification, and the principle of correction. The function of norm is not exclusion, rejection. On the contrary, it invariably involves the technique of positive intervention and transformation, with a certain kind of normative project » [2, p. 73]. Foucault demonstrates how a new type of power is realized by three anthropological practices of modernity (medical, educational, law enforcement) $[3,4,5]$, which follow the new paradigm of «norm-deviation» with the help of the developed technologies - normalization, subordination, discipline. This new type of power Foucault calls «power-knowledge», because it is derivative from modern sciences. And psychiatry, being born from within the medical discourse having long history, subordinates discourse of madness the new paradigm «norm-pathology» [6].

My purpose is to show how the transition from medical psychiatric discourse in psychoanalysis led to the abandonment of the «power-normalization» and, accordingly, what changes have occurred in the communication structure in the system of therapist / client and in the space of ethos. The thesis is formulated as follows: the result of «mutation» of psychiatric discourse carried out by psychoanalysis, psychotherapy was the appearance in European culture as a new version of the «practices of myself». Foucault defines the practices of myself as follows: «This means the thought-out and voluntary practices by which people do not just set for themselves rules of conduct, but try to change ourselves, to transform themselves in their own particular being and make his life a creation that carries a certain aesthetic values and certain criteria of style», getting the opportunity to perform on themselves by some operation - something to do with the body, soul, thoughts, etc. [7]. These «arts of existence» in the history of different countries and peoples were holistic cultural systems that have been passed from one generation to the next, they had not only the technical part, but also develop an idea of what 
necessary to take care of itself - the teaching of worthy and correct life, necessary not to neglect it, not to let it take its course - i.e. a certain practical philosophy of life.

Practice of myself existed and exist in parallel with the practices of socialization and normalization, obedience and discipline, they have different objectives: if at the heart of the first a man himself puts perfection in the way of a decent life, the other tends to make the individual a good member of society. These objectives cannot contradict one another, and may enter in certain periods of history in conflict. In order that «to practice myself» I have to be able to establish distance among me and me, to find a certain ability to distinguish me from my thoughts, speeches, actions, feelings, etc. This ability is not given to a man by nature - it is quite late acquisition in history and in ontogenesis. But it is not only the capacity for reflection, it is a question of a person's ability to take his own life as an author's project. Therefore, there is need to explore the cultural and historical conditions conducive to the simultaneous appearance of the historical phenomenon of authorship, and practices of myself. However, the most important thing to understand what is «generating attitude» [8], the generative matrix that produces and reproduces the opportunity to manifest this phenomenon.

Culture of myself has different historical topoi, they existed not always and not everywhere, and it is interesting: what cultural, historical and anthropological conditions needed for this? In our cultural and historical reversal it is interesting to reconstruct an important moment in European history and chronologically reveal the time of manifestation of the phenomenon of subjectivity (personality), to draw an analogy between ancient practices of myself and psychotherapy. This occurs during the transition from archaic heroic society of ancient Greece to the classic Hellenistic period, associated with the birth of the European philosophical tradition in the antique polises-states. There is a distinction between what is universally human, and that has a local origin nature of the Athenian community due to the emergence of a larger community dimension, which unites the whole complex of Greek polises-states.

In archaic society, everyone has his role in the system of rigidly prescribed roles and statuses that are defined by key structures of kinship and maintenance of the house. Specific rules require people to their place in the social order, and thus define their identity, without that person could not know who he is - he is identical with his social role. The unity and the meaning of human life can be made under these establishments, out of which is no possibility of self-determination, a man, in fact, is a functional link in the social system. In Athens (the classical period of Greek history), as A. Mcintyre shows, the concept of moral virtues becomes torn off from a concrete social role [9], and this was reflected in the antique tragedy, there was a distinction meanwhile what is universal for mankind, and what has local Athenian character. Now possible conflict between ethical alternatives «be a good person» and «a good citizen» (as in «Antigone» by Sophocles). In Europe, for the first time there is the very idea of the «man in general»-irrespective of who he is in the local society. Human subjectivity is first encountered with the possibility of internal conflict (local-social and universal-human), which can be overcome through constitution of the «I», which is able to choose between alternatives, taking a reflexive stance. This requires to develop the attitude to each of them, which means to set the distance between me and my possibilities of self-determination, which I have to consider and evaluate. Self-consciousness manifests itself in a conflict between two equally valuable identify prospects between two equally possible value-semantic systems. Identity is not given ritual and / or regulatory, self-defining «I» is formed through a resolution of clashing moral alternatives, each of which is problematic in the sense that is not an absolute good or evil. The symbolic nature of «good» and «evil» (ethical values) requires of the hermeneutic disclosure, formed by at least two possibilities for autonomous self - freedom of interpretation and freedom of action, brings to life the values with which person identifies itself. Possibility for author's attitude to the own life appears together with the presence of existential/ethical choices, and that, in turn, supposes responsibility for itself, which can not be passed on to another person.

Formation of phenomenon «I myself» (self-consciousness) into the classical Hellenistic era stimulated the birth of ancient philosophy. During this period, philosophy - it is a practical philosophy, «culture of myself», and this is no accident. It emerges as a theory and practice for cultivating of such subjectivity, the inner structure of which conflict and which requires a new skill to cope with the «burden of freedom». The Stoics, Cynics, Epicureans, and others practicing different types of «self-care» - the practice of myself, helping the personality, first appeared in history, separated from the social role, to deal with a variety of ethical and other mental problems that could not have been at their heroic ancestors. Of course, this «culture of myself» was not narrowly «psychological» case, in this practice we can see the unity and spiritual, and psychological, and medical and educational, and ethical, and social aspects, many of which are «privatized» psychotherapy.

In late antiquity the practices of myself received institutional forms - classical Greek philosophical schools were nothing more than a different species of culture of myself, transmitting certain traditions in the «arts of existence». A single never practices, the other is always necessary for that practice as a carrier and transmitter its various forms. In different historical forms of such practices it was someone who always helps a person to care for himself, whether it be a master of martial arts, or teacher-philosopher in the antique practices of myself. An interesting parallel with modern psychotherapy - it was not a single philosophy, there were many philosophical schools. Later, in Rome, philosophers widely extended philosophical concepts and methods, offered samples. In society, there were texts that served as something of a textbook on the practice of myself. There were professional philosophers, 
engaged in private practice. They, by the way, as well as modern therapists perceived ambiguous, often become the object of a sneer. Acquaintance with Foucault's book «Hermeneutics of the subject» [10], devoted to the culture of myself developed by the schools of late antiquity, reveals many similarities with modern psychotherapy, and it makes us think about its historical analogues and / or prototypes.

Human freedom is constitutively associated and most clearly manifest in the phenomenon of subjectivity / authorship. To it we must seek to understand the essence and meaning of the cultural lacuna that made up thanks to the emergence psychoanalysis. Now, if psychotherapy has become necessary, we have to assume that its axiological base, targeted programs and methods are derived from its «historic mission», no matter what the founding fathers think about it. Practices of myself becomes historically necessary during those periods when in a society there are no absolute and indisputable sources of values for orientation in life, when rigid normative systems fall. It happened in the antiquity during the disintegration of the traditional religion (mythological consciousness), as well as in the period of transition to the postmodern as modern science has experienced the first crisis and has lost credibility in matters relating to the human soul $[11,12]$. Emergence of psychoanalysis on a historical scene doesn't seem casual if to look at the matter in such foreshortening.

\section{What Psychoanalysis Had Changed in Psychiatry?}

Medical discourse of psychiatry submits to the principle of causality, accepted in the natural sciences. Thereof, the concept of mental norm has no connotations that can impute a patient responsibility for his state: disease is not considered as something, what a person bears responsibility. It is a natural consequence of the convergence of many factors and reasons. Historically, this idea of «madness» was the conquest of humanity: psychiatry has replaced that practice, when «crazy» qualified as «monster», ostracized and slighted as the public evil. However, this humanism has a reverse side.

Psychiatry could make treatment of the «insane» more humane only due to a peculiar depreciation of a person by removing the responsibility for itself, making it the object of care from another person allocated with authority and knowledge -an object of the power-normalization. Realizing suffering soul as illness, thereby placing it in the department of natural sciences, psychiatry can talk about a man, about a personality (turning it into object of action, objectifying it), but it does not appeal to person - to its freedom and to its responsibility.

Let's compare how can and must deal with itself a persona patient of psychiatric clinic and the one who comes to a therapist. A man walking to a psychiatrist for the help acts with himself in the same way as he acts with a thing when wants to investigate and change it, - turns himself into object of studying. To do this today in his hand there are scientific methods, and he appeals to medicine, to the correctional psychology and pedagogy, psychiatry. In psychiatry, the knowledge is obtained not through the interpretation of various phenomena (symptoms, problems, etc.), which manifests the disease state, but by the objective scientific observation of the behavior of the patients, the systematization, summarizing and typology of symptoms and syndromes, on what basis categorical nosological system is built. Further - diagnostics - an investment of objective indicators of behavior of a patient or other «facts» to this scheme which works within the general paradigm of anthropological practices of modernity «norm - deviation». A person thus is the object of qualification for compliance with a norm and an object of different - medical, legal, educational technologies in order to bring it into conformity with it: so society realizes the «power-normalization» of individuals.

This paradigm in psychiatry operates so that a patient has no opportunity to decipher for himself its feelings, experiences and states. Instead of him it makes a psychiatrist, a patient gets ready (educational or medical) advice and destination. This means that his life, feelings and states are not problematized by itself, can not become his own experience, a meaningful component of the whole his soul. He has no practice of himself, giving himself at the full disposal of a professional. As a result of this normalization process there is a certain product - individual, fitting to the social system as its well-regulated functional units having minimum degrees of freedom and space for autonomous self-determination. Practices of normalization, justifying their public legitimacy on the foundation of scientific knowledge and implementing the subject-object structure of communication not allow to manifest phenomenon of subjectivity, there people are always objects of professional action, and professional itself, as an active agent of such practice, only in rare cases becomes the subject of it, when creatively transforms it.

In psychotherapy - it is not so. It provides an opportunity for the problematization of the circumstances, anxiety, relationship with others and so on, whereby the psychological condition and life situation can be understood, and horror looming outside, threatening the collapse of existence, can be mastered inner fear, to receive the address and residence in the soul, that allows to ask yourself the question of how to cope with it. Despite the fact that psychoanalysis operates on the same theoretical constructs that psychiatry, i.e. the categories of neurosis, psychosis, the concept of the disease, however, this knowledge is built in a completely different from the clinical system of physician-patient relationship, and it means the formation of a new paradigm in psychological practice.

Therapist involves a client in such contacting with itself, which it may to think of itself, to address himself, to problematization itself rather than turning itself into the 
object for another person for subsequent consumption of the finished product - the knowledge or tablets. Client is offered to abandon his setting not by persuasion, but by building (implementing, rather than declaring) new rules for relationships. It means to invite for dialogue, give the place and time of the client's speech, to hear his mind, but not to listen with purpose of assessment and diagnosis, to take seriously what he says and how. However, therapist knows that a client is not (always) comes ready for such contacting with himself: he has yet to become a client, i.e. the subject of such practice of himself, such care of himself. Most of them come with the previous setting as to expert (doctor) for knowledge, prescriptions and so forth. Therefore, therapist, involving a client in such care of himself, produces not just something that helps get rid of suffering, but neither more nor less than a cultural and anthropological transformation: from a man-consumer (user) medical (psychological, educational, legal) services occupying the position of the object of activity, he «makes» a person the subject of the proposed practices and, ultimately, the subject of his own life.

The essence of the «mutation» of clinical discourse of psychiatry that occurred as a result of the birth of psychoanalysis and all the changes we are talking about, was that the «norm» has disappeared from the very relationship between doctor and patient, it ceased to be a regulatory guide. Demarcation criteria for distinguishing between medical and psychotherapeutic discourse is applying the norm as the axiological basis of practice and the foundation of its target program. Psychoanalysis has changed the axiological bases and target program of practice: bringing the patient to normal happens not because it is regarded as a paramount importance and is the psychotherapy purpose. Now the goal is different: a patient must come to understanding the effect of unconscious mechanisms of his psyche, and the disappearance of a symptom occur (or not) when a patient knowingly refuses him (or not), having reached self-understanding in dialogue with therapist. F. Perls - the founder of Gestalt therapy writes: «A task of the psychotherapist not in that, - as often mistakenly think, - "to find out" that not so from the patient, and then "tell it". $<\ldots>\ldots$ it is important that the therapist taught the patient to learn these or those things about himself» [13].

\section{Ethos of Psychotherapy}

Having acquired a radically new dimension as the «meaning» symptom ceases to be a something necessarily destroyed. Therefore, the axis of discourse, which Foucault calls «ethos», is undergoing significant transformation. Before the patient persistently raises the need to choose, because a symptom, as we know, is desirable and has a stabilizing protective function and was the result of previously unconsciously made choice that now it is necessary to understand and to revise. Solution, which is now to be taken, a psychoanalyst (even very prescriptive and nurture) can not do instead of analysand. Making the choice, a patient takes a step to ensure that free from the compulsion symptom, however, this freedom is expensive - a person now has to be responsible for their own destiny, abandoning the painful symptoms, in fact, he takes the new (old) problems, way avoiding of it once was the symptom. Here we see another difference from the clinic: psychoanalysis does not imply work with the symptom or disease as such, but with the whole life, the whole personality of patient.

The principles and diagnostics, and therapies in psychiatry absolutely others: diagnostics relies on objective researches and supervision, and treatment is based on direct pharmacological or psychological interventions. Thus, the main change in comparison with psychiatry consists that the patient stops being an object of medical intervention and becomes the participant of psychotherapeutic process, and it means opportunity for author's interpretation of the psychotherapeutic experience, that is always connected with integrity of the whole existence of a person. Of course, psychoanalysis (and all subsequent psychotherapy) is a social institution, and thus involved in the need for social justify their practices. Thereby psychotherapist accepting «mental norm» as the purpose of the activity, but to the extent that these activities should be socially justified. In reality, therapist guided somehow understood «good» for patient. The substantial aspect of these values can make the subject of a separate analysis, it is only important that each school develops its own idea of this «good», and although the «health» is included in this range, but it acts as a «good» rather than the norm. «Possible to consider as "success" not healing in the sense of the finished product, but the empowerment of human resources and capabilities to cope with problems arising at it», - F. Perls writes [14].

Understanding the meaning of what is happening in your own soul is always associated with transformation, change of yourself. This is due to a direct connection between self-understanding and self-transformation, in fact, it is one process, which performed by phenomenological-hermeneutical method. The strategic outcome of psychotherapy is that a client becomes the subject (and not the object) cognitive, reflective, moral, value (or any other) judgments about itself that, in turn, means the establishment of critical distance between me and me, a full-fledged step in the development of subjectivity (personality, self-awareness, etc.). Make the subject of a patient, not the object of «disease», paradoxically sounds - is the purpose of psychotherapeutic dialogue. And because this is so, then it is not a «natural» process: a patient is involved in it like a man as such, assigning to itself authorship and responsibility for his life. Consequently, in this process it is not necessary to speak about a natural causality. It goes no natural chain of cause and effect, which a physician is trained to eliminate by means of the medical technologies, but from the future - idea of the good (ideals, values), not causally, but intentional (if only psychotherapy is carried out in 
compliance with own, instead of medical paradigm).

Phenomenon of the author's attitude to its own life does not obey the causal mechanisms, it happens as the event and occurs when there are prerequisites for generative relations for the event: in the conditions of the conflict structure of self-consciousness, which manifests as a challenge, as a task for a person. Man becomes necessary to think about itself, about its life situation and perspective, to reconsider its position in the value-semantic coordinates, it means not «objectify» but «problematize itself». Problematization of itself here means revision of the reference system of valuable and vital reference points as a whole, preparing the new choice of itself, the new form of subjectivity which would be more integrated and viable. This is obviously what is needed in crisis situations that therapist has to do.

The philosophical rethinking of the «subject», according to Foucault, is that the process of subjectivation is conceived not as carried out in the immediate givens of consciousness of itself (the Cartesian cogito), but with the help of hermeneutics itself, problematization and study itself, that Foucault calls practice of itself. To analyze what is denoted by the term «subject», - Foucault further writes - should raise the question of the forms and modalities of the relationship to itself, by means of which the individual constitutes himself and recognizes himself as such. Foucault writes that for the analysis of the formation of a real human subjectivity must be «... not analyze the behavior and ideas, not of society and not their «ideology», but problematization by which existence given to itself as something that can and should be thought out, and practices on the basis of which this problematization are formed» [15].

Foucault reveals the meaning of the concept of ethos as «a certain kind of relationship to the actual circumstances; voluntary choice, performed by people, a way to think and feel as well as how to act and behave, which also expresses a certain belonging and presents itself as a task» [16]. Psychotherapy implements one of the possibilities for the formation of such a space, along with the traditional «private» spheres of life, raising these practices of itself to a new cultural level by professionalizing of them. The need for such a practice is linked to the historical fact that the space of ethos in the anthropological practices of modernity has been disappeared because of their rootedness in an ethically neutral science. Some general cultural revolution occurred in the recent period with the birth of psychotherapy.

So, if to understand by «ethos» cultural space for independent value-semantic self-determination, we can look at psychotherapy as a new dialogical germeneutics culture of myself, which replaced the anthropological practices of modernity, exercising the «power-normalization». Dialogue principle generates the whole system of value-semantic space of psychotherapy on the grounds that there does not exist an absolute point of reference such as «norm» - in psychotherapy the base coordinate system is built on only the attitude of «I» to another human.

\section{Conclusions}

Relying on M. Foucault's researches, it is possible to offer theoretical criterion of demarcation of two types the practices about which there was a speech. Such criterion is a way that person is dealing with itself. In the anthropological practices of modernity people exposes itself to the procedure of objectivization. In the practices directed on self-understanding and self-change as it happens in psychotherapy there is a new opportunity for such form of dealing person with itself which Foucault calls «problematization of itself», «stand itself under the question». There is a new possibility of that relation to own life which can be recognized as authorship.

Psychoanalysis has created an opportunity for psychotherapy by not the content of its theories (which, as shows the subsequent history of psychotherapy, may be replaced by others), but by changing the structure of the communication in the system of the therapist / client, building a practice on the principles of dialogism and subjectivity / authorship. In psychoanalysis there was carried out a hermeneutic circle in the structure of communication between actors, i.e. a cyclical process in which dialogue participants can reach a common understanding, building a single «horizon of meaning» [17].

In summary it is necessary to make one important remark and to emphasize that paradigmatic features are not those empirical characteristics what these or those available forms of psychotherapy can hold. The paradigmatic principles have nature of obligation, i.e. have to be carried out if this or that concrete psychotherapeutic model seeks to follow the cultural and anthropological mission (its $\langle\tau \varepsilon \lambda \mathrm{\alpha} /{ }\rangle$, according to Aristotle). To reveal the philosophical bases of psychotherapy means to define its $\langle\tau \varepsilon \dot{ } \mathrm{o} \mathrm{\varsigma}\rangle$.

\section{REFERENCES}

[1] Fuko, M. (2004a). Arheologija znanija. SPb.: IC «Gumanitarnaja akademija»; «Universitetskaja kniga».

[2] Fuko, M. (2004b). Nenormal'nye: Kurs lekcij, prochitannyj $v$ Kollezh de Frans v 1974-1975 uchebnom godu. SPb.: Nauka. - P. 73.

[3] Fuko, M. (2004b). Nenormal'nye: Kurs lekcij, prochitannyj v Kollezh de Frans v 1974-1975 uchebnom godu. SPb.: Nauka.

[4] Fuko, M. (2007a). Psihiatricheskaja vlast': Kurs lekcij, prochitannyh v Kollezh de Frans v 1973-1974 uchebnom godu. SPb.: Nauka.

[5] Fuko, M. (1999). Nadzirat' i nakazyvat': rozhdenie tjur'my. M.: Ad Marginem.

[6] Fuko, M. (1998). Rozhdenie kliniki. M.: Smysl.

[7] Fuko, M. (2007b). Germenevtika sub\#ekta: Kurs lekcij, prochitannyh v Kollezh de Frans v 1981-1982 uchebnom godu. SPb.: Nauka. - P. 17. 
[8] Mihajlov, F.T. (2001). Izbrannoe (1990-2000 godu). M.: Indrik.

[9] Macintyre, A. (2007). After Virtue: A Study in Moral Theory. (3rd ed.). University of Notre Dame Press.

[10] Fuko, M. (2007b). Germenevtika sub\#ekta: Kurs lekcij, prochitannyh $v$ Kollezh de Frans v 1981-1982 uchebnom godu. SPb.: Nauka.

[11] Gusserl', Je. (2000). Krizis evropejskih nauk $i$ transcendental'naja fenomenologija. In Je. Gusserl', Logicheskie issledovanija. Kartezianskie razmyshlenija Mn.: Harvest, M.: AST. - S. 543-624.

[12] Ortega-i-Gasset, H. (1996). Istorija kak sistema. Voprosy filosofii. 6. - S. 78-103.
[13] Perlz, F. (1993). Opyty psihologii samopoznanija. Praktikum po geshtal'tterapii. M.: Gil'-Jestel'. - P. 27.

[14] Perlz, F. (1993). Opyty psihologii samopoznanija. Praktikum po geshtal'tterapii. M.: Gil'-Jestel'. - P. 26.

[15] Fuko, M. (2004c). Ispol'zovanie udovol'stvij. Istorija seksual'nosti. T. 2. SPb.: Akademicheskij proekt. - P. 19.

[16] Foucault, M. (1994). Qu'est-ce due les Lumieres? // Dits et Ecrits. Vol. IV: 1980-1988. P.: Gallimar. - P. 568.

[17] Gadamer H.-G. Istina $i$ metod: Osnovy filosofskoj germenevtiki. M.: Progress, 1988. 